\title{
Ti-10V-2Fe-3Al 合金の強度と勒性におよぼす溶体化処理の影響*
}

\author{
宗木政一** 河部義邦** 高橋順 次**
}

J.Japan Inst.Metals, Vol.51,No.10(1987),pp.916-922

Effect of Solution Treatment on Strength and Toughness in Ti-10V-2Fe-3Al Alloy

Seiichi Muneki**, Yoshikuni Kawabe** and Junji Takahashi**

The effect of the solution treatment in the range from two phase $(\alpha+\beta)$ to $\beta$-fields on the strength, ductility, and toughness of $\mathrm{Ti}-10 \mathrm{~V}-2 \mathrm{Fe}-3 \mathrm{Al}$ alloy has been investigated. When the solution treatment was performed in the temperature range from 973 to $1173 \mathrm{~K}$, the $0.2 \%$ yield strength showed a noticeable decrease at $1043 \mathrm{~K}$ or higher and was only about $450 \mathrm{MPa}$ or less. In contrast with these variations the elongation showed a great increase.

It is considered that these variations of the $0.2 \%$ yield strength and elongation arise from the stress induced martensitic transformation due to the instability of the $\beta$ phase matrix. After aging at $783 \mathrm{~K}$ for $28.8 \mathrm{ks}$, the $0.2 \%$ yield strength did not show any sharp decrease like that in the solution treated condition. Both elongation and reduction in area showed a considerable low values at $1073 \mathrm{~K}$ or higher. However, the detrimental effect of coarsening of $\beta$ grain size was not detected from the mechanical properties because of their very small absolute values of ductility. On the other hand, the notch tensile strength and $K_{\text {IC }}$ were not affected by the microstructural change at the same strength level. Notch tensile strength was not affected by the strength but $K_{\text {IC }}$ showed a decrease with an increase of the strength level.

It was confirmed that the superior combination of strength, ductility, and toughness after aging treatment at $783 \mathrm{~K}$ for $28.8 \mathrm{ks}$ was obtained with the solution treatment at sub-transus temperature of $1023 \sim 1043 \mathrm{~K}$.

(Received April 9, 1987)

Keywords: titanium-vanadium-iron-aluminum alloy, solution treatment, instability of beta phase, elongation, reduction of area, yield strength, fracture toughness, notch tensile strength, lattice parameter of beta phase

\section{I ． 緒言}

航空・宇宙, 海洋開発, 原子力平和利用などの先端技術 分野では, 高比強度の構造材料が必要とされ, 例えば航空 機材料には超強力鋼, $\mathrm{Ti}$ 合金, $\mathrm{Al}$ 合金と複合材料がその 特徴に応じて使い分けられている。そのなかで Ti 合金は, 軽量, 高強度で耐食性と耐熱性に優れた構造材料である. この $\mathrm{Ti}$ 合金には, $\alpha$ 型, $\alpha-\beta$ 型と $\beta$ 型の 3 種があり, 現 在広く実用化されている Ti-6Al-4V 合金は， $\alpha-\beta$ 型に 属する.乙の $\alpha-\beta$ 型合金は, 焼入性, 低温·中高温の機 械的性質, 溶接性などが平均的に優れ，バランスのとれた 信頼性の高い合金とされている.と乙ろが，チタンの低温 安定相である $\alpha$ 相を母相とするため冷間加工がほとんど できず，また，時効硬化性が低い欠点がある。乙れに対し て, VやMoなどを多量に添加すると, 高温相の $\beta$ 相の 安定性が高められ, 加工の容易な体心立方晶が室温にもち
きたされる。

本研究は, 高強度で高靱性を示す $\mathrm{Ti}-10 \mathrm{~V}-2 \mathrm{Fe}-3 \mathrm{Al}$ 合 金について, 組織之機械的性質におよぼす溶体化処理の影 響を検討したものである. 本合金は，鍛造性が優れ，破壊 勒性が高く, Ti-6Al-4V 合金の一部に置き換わる材料と して注目されている. また, 他の $\beta$ 型合金よりも $\beta$ 安定 化元素量が低く抑えられているため, $\alpha-\beta$ 型と $\beta$ 型の中 間に位置づけられて near $\beta$ 型と呼ばれ, $\beta$ 相の安定性が 比較的低いのが特徴である.

一般に $\beta$ 型合金は， $\beta$ 変態点直下または直下の温度で溶 体化処理され, 引き続いて $773 \mathrm{~K}$ 近傍の温度で時効好理さ れる. Ti- $10 \mathrm{~V}-2 \mathrm{Fe}-3 \mathrm{Al}$ 合金の場合, 標準の熱処理 ${ }^{(1)}$ とし て変態点直下の $1033-1053 \mathrm{~K}, 3.6 \mathrm{ks}$ 溶体化と 768-798 K, $28.8 \mathrm{ks}$ 時効の条件が示されている. そして，乙の標準に近 い条件で熱処理された Ti-10V-2Fe-3Al 合金については, すでに幾つかの報告 ${ }^{(2)-(4)}$ がある.すなわち，本合金は上 記のように他の $\beta$ 型合金よりあ $\beta$ 安定化元素量が低く抑

\footnotetext{
** 金属材料技術研究所筑波支所 (Tsukuba Laboratories, National Research Institute for Metals, Sakura-mura, Ibaraki)

* 1984 年 4 月日本金属学会習志野大会に発表
} 
えられているため, 溶体化材を室温で引張試験すると応力 誘起マルテンサイト変態が発生 ${ }^{(3)}$ する。.また, 各温度での 溶体化処理とその後の時効処理による組織変化 ${ }^{(3)}$ について, 更に初析 $\alpha$ 相の量, 形態之強度, 延性との関係 ${ }^{(5)}$ などに ついてはすでに報告されている.

そこで, 本研究は $\beta$ 変態点の上下 $100 \mathrm{~K}$ 範囲で溶体化 処理を行ない. 上記応力誘起マルテンサイトの生成挙動さ らに初析 $\alpha$ 相や $\beta$ 粒径などの組織変化と機械的性質, 特 に切欠鞀性，破壊勒性などとの関係を検討することを目的 として行われたあのである.

\section{II. 実 験 方 法}

供試材は，プラズマ・電子ビーム溶解炬による二重溶解 により約 $5.5 \mathrm{~kg}$ のインゴットを作製した。その化学分析 結果は, Table 1 に示すようにほぼ目標どおりで, 酸素 は $0.078 \%$ であった．てのインゴットを真空中 $1273 \mathrm{~K}$ で $18 \mathrm{ks}$ の均質化処理を行った後, 大気炉中で $1273 \mathrm{~K}, 3.6$ $\mathrm{ks}$ 加熱してプレスで $60 \mathrm{~mm}$ 角にして室温まで泠却した。 その後, $1273 \mathrm{~K}$ に加熱して $1173 \mathrm{~K}$ から $1073 \mathrm{~K}$ の温度で 総加工度 $86 \%$ の熱間圧延を行い，11 mm 角棒を作製し た. 圧延終了後は直ちに水中に急冷した．溶体化処理は， 乙の合金の $\beta$ 変態点が $1073 \mathrm{~K}$ 近傍と報告(1)(6) されている ので, $\beta$ 変態点 $\pm 100 \mathrm{~K}$ の $973 \mathrm{~K}$ から $1173 \mathrm{~K}$ までの温度 で $3.6 \mathrm{ks}$ 行い水冷した。時効処理は, 乙の合金の標準的

Table 1 Chemical composition of Ti-10V-2Fe$3 \mathrm{Al}$ alloy used $(\operatorname{mass} \%)$.

\begin{tabular}{c|c|c|c|c|c|c|c}
\hline \hline $\mathrm{V}$ & $\mathrm{Fe}$ & $\mathrm{Al}$ & $\mathrm{C}$ & $\mathrm{N}$ & $\mathrm{O}$ & $\mathrm{H}$ & $\mathrm{Ti}$ \\
\hline 9.75 & 2.05 & 2.78 & 0.014 & 0.0155 & 0.078 & 0.013 & Bal. \\
\hline
\end{tabular}

な熱処理条件の $783 \mathrm{~K}, 28.8 \mathrm{ks}$ の一条件のみを採用し, いずれの熱処理もすべてソルトバス中で行った.

組織観察用試料は, 振動式自動研磨機を用いて研磨し, $10 \%$ 硝酸・フッ酸水溶液で腐食した。なお， $\mathrm{CuK}_{a}$ 線を 用いた X 線回折により相の同定を行い, $(200) \beta$ 之 $(10 \cdot 0) \alpha$ の回折線を用いて $\alpha$ 相の体積率，そして (200) $\beta$ の $2 \theta$ から $\beta$ 相の格子定数を求めた.

引張試験は, すべての熱処理が終了したのち平行部長さ $14 \mathrm{~mm}$, 直径 $3.5 \mathrm{~mm}$ の丸棒引張試験片を作製し, 溶体 化材については $1.67 \times 10^{-6} \mathrm{~m} / \mathrm{s}$, 溶体化時効材について は $1.67 \times 10^{-5} \mathrm{~m} / \mathrm{s}$ のクロス・ヘッド速度で大気中で試験 した。

切欠引張之破壊勒性試験は, 溶体化時効材についてのみ 行った。 な抢, 切欠引張試験は, $\mathrm{k}_{\mathrm{t}} 3.5$ の円周切欠付丸棒 試験片を用い, クロス・ヘッド速度 $1.67 \times 10^{-5} \mathrm{~m} / \mathrm{s}$, 大 気中で試験した。平面歪破壊勒性 $\left(K_{\mathrm{IC}}\right)$ 試験は, 長さ 100 $\mathrm{mm}$, 厚さ $10 \mathrm{~mm}$, 幅 $20 \mathrm{~mm}$ の三点曲げ試験片を用い, ASTM E $399^{(7)}$ 亿基づいて大気中で行った.

\section{III. 結果}

\section{1. 溶体化材の組織之機械的性質}

Fig.1は，973 K から $1173 \mathrm{~K}$ までの温度で $3.6 \mathrm{ks}$ 溶体 化処理を行った際の光学顕微鏡組織の変化を示したもので ある. $973 \mathrm{~K}$ の溶体化処理では, 熱間圧延時の加工組織が 残存した未再結晶組織である. $1023 \mathrm{~K}$ になると, 加工組 織は消滅するが, 再結晶はまだ部分的である。溶体化処理 温度が $1043 \mathrm{~K}$ に上昇すると，ほぼ再結晶粒組織となるが， 結晶粒径はすでに約 $150 \mu \mathrm{m}$ である．溶体化処理温度が上 昇すると, さらに粒径の粗大化が進行し, $1173 \mathrm{~K}$ 溶体化

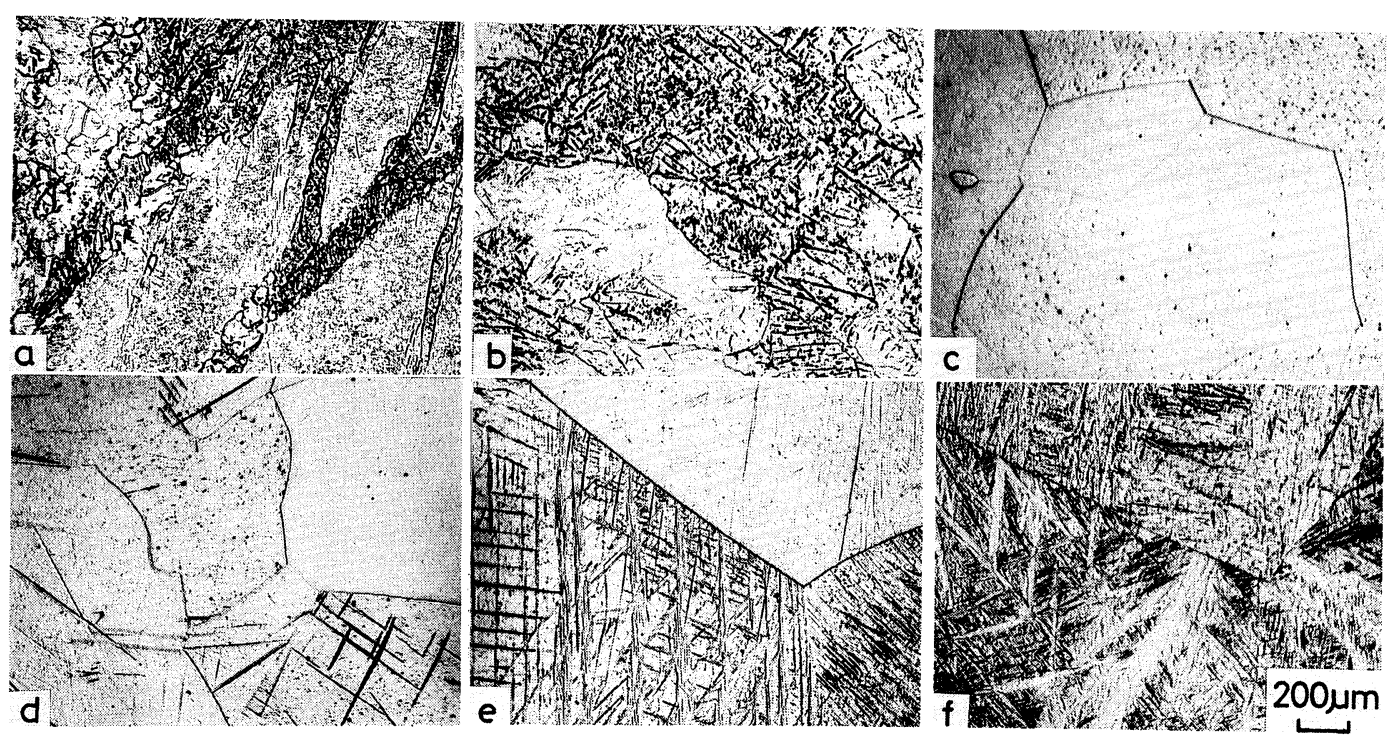

Fig.1 Optical micrographs of Ti-10V-2Fe-3Al alloy as solution treated for $3.6 \mathrm{ks}$ at: (a) 973 $\mathrm{K}$, (b) $1023 \mathrm{~K}$, (c) $1043 \mathrm{~K}$, (d) $1073 \mathrm{~K}$, (e) $1123 \mathrm{~K}$, and (f) $1173 \mathrm{~K}$. 
材では約 $450 \mu \mathrm{m}$ に達した。

Fig. 2 は，相変化におよぼす溶体化処理温度の影響を示 した X 線回折の結果である. $973 \mathrm{~K}$ と $1023 \mathrm{~K}$ の溶体化処 理では， $\beta$ 相と $\alpha$ 相の 2 つの相が同定された。とてろが $1043 \mathrm{~K}$ になると，乙の 2 相のほかに斜方晶マルテンサイ 卜 $\left(\alpha^{\prime \prime}\right)^{(8)}$ も同定された。ささらに，1073 K になると $\alpha$ 相が 消滅し， $\beta$ と $\alpha^{\prime \prime}$ の 2 相組織となっている. Fig.1の 1073 $\mathrm{K} よ り$ 高温側の溶体化材にみられる針状あるいはレン ズ状組織が，乙のマルテンサイト組織である。

このように, 本実験合金は溶体化処理温度が $\beta$ 変態点 近傍以上の場合, 溶体化状態ですでに少量のマルテンサイ トが生成しているのが特徴で，また $\beta$ 変態点は $1073 \mathrm{~K}$ と $1043 \mathrm{~K}$ の間にある.

Fig. 3 は，溶体化材の引張性質におよぼす溶体化処理温 度の影響を示したものである。引張強さは，973 K におい て約 $800 \mathrm{MPa}$ を示し, 温度の上昇にとむない減少し, $1043 \mathrm{~K}$ において約 $700 \mathrm{MPa}$ となるが，さらに温度が上昇 してもほとんど変化しない．それに対して，0.2\% 耐力は 特異な挙動を示す。すなわち，973 K および $1023 \mathrm{~K}$ では 引張強さとほぼ同様の傾向を示すが，1043 K において急 激に低下して約 $450 \mathrm{MPa}$ となる。乙の值は，1053 K で溶 体化処理した Duerig ら ${ }^{(3)}$ の結果(耐力：468 MPa)に近い 值である，さらに，温度が上昇すると，ばらつきが多少あ るが， $0.2 \%$ 耐力は引張強さと比べてやはり著しく低い值

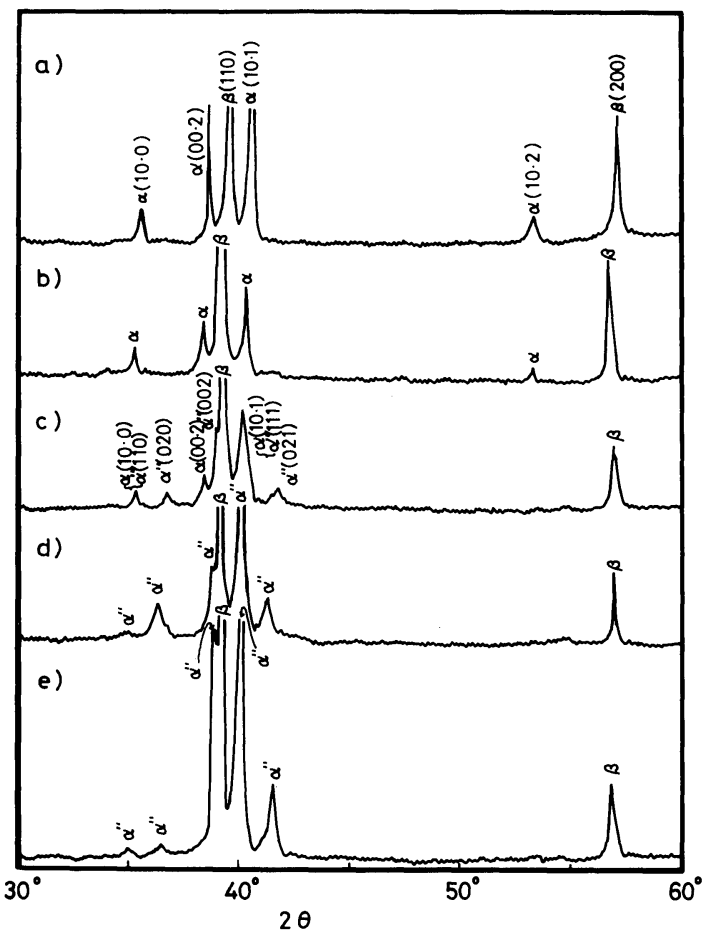

Fig.2 X-ray diffraction profiles of Ti- $10 \mathrm{~V}-2 \mathrm{Fe}$ $3 \mathrm{Al}$ alloy as solution treated for $3.6 \mathrm{ks}$ at : (a) $973 \mathrm{~K}$, (b) $1023 \mathrm{~K}$, (c) $1043 \mathrm{~K}$, (d) $1073 \mathrm{~K}$, and (e) $1173 \mathrm{~K}$.

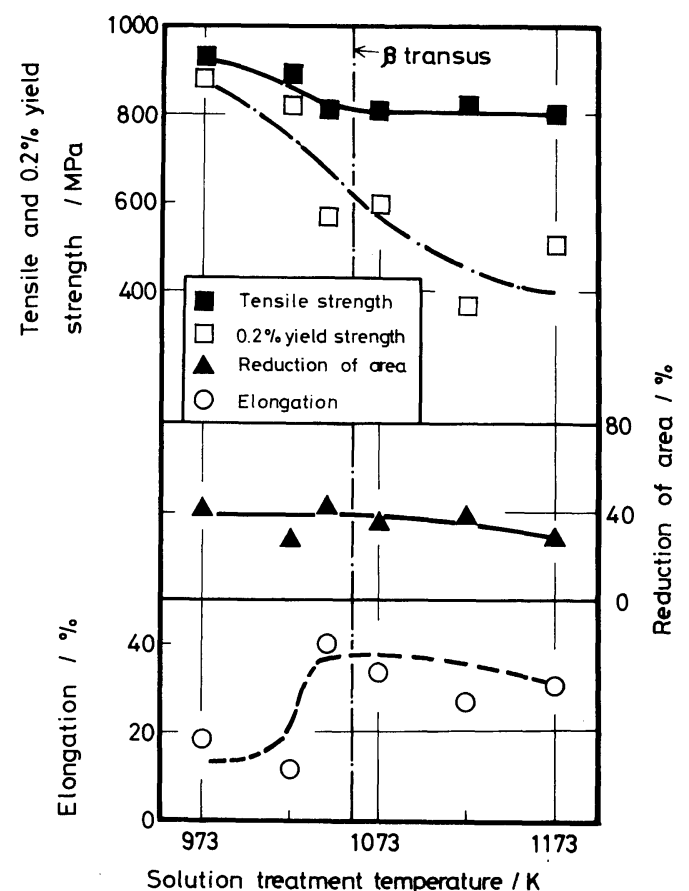

Fig.3 Effect of the solution treatment temperature on the mechanical properties of $\mathrm{Ti}-10 \mathrm{~V}$ $2 \mathrm{Fe}-3 \mathrm{Al}$ alloy.

を示している.

延性については，伸びと絞りでその挙動が異なっている． すなおち, 絞りは溶体化処理温度が上昇してあほぼ一定の 35-40\% を示している. てれに対して伸びは, $973 \mathrm{~K}$ と $1023 \mathrm{~K}$ では 20-10\% の低い值であるが， $1043 \mathrm{~K}$ で $40 \%$ まで急激に増加し，さらに温度が上昇する之ゆるやかに低 下する傾向を示した。

てのように, 溶体化材では $0.2 \%$ 耐力と伸びにおいて溶 体化処理温度の影響が顕著に認められた。

\section{2. 溶体化時効材の機械的性質}

Fig.4 は, 各温度で溶体化処理後, $783 \mathrm{~K}$ で $28.8 \mathrm{ks}$ の 時効処理を施した試料についての X 線回折による相同定 結果である.いずれの溶体化処理温度の場合も, $\beta$ 相亡 $\alpha$ 相の 2 相が同定され, 溶体化材で認められた $\alpha^{\prime \prime}$ 相は同定 されない. また, Fig.5に示したように，引張強さと $0.2 \%$ 耐力が同様の傾向を示し, 溶体化材のような $0.2 \%$ 耐力の 急激な低下は認められない。しかも，973 K から $1073 \mathrm{~K}$ にかけて強度は逆に約 $200 \mathrm{MPa}$ 上昇し，1073 K から 1173 Kにかけてやや低下する.

また，伸びと絞りは同様の傾向がみられるが，特に変化 の大きい絞りに注目すると, $973 \mathrm{~K}$ から $1023 \mathrm{~K}$ にかけて ゆるやかに減少し，1043 K を径て $1073 \mathrm{~K}$ にかけては急激 に低下し，1073 K 以上ではほぼ一定よなり，1173 K でわ ずかに低下している。

切欠引張強さは, $1600 \mathrm{MPa}$ 以上の非常に高い値を示し, 


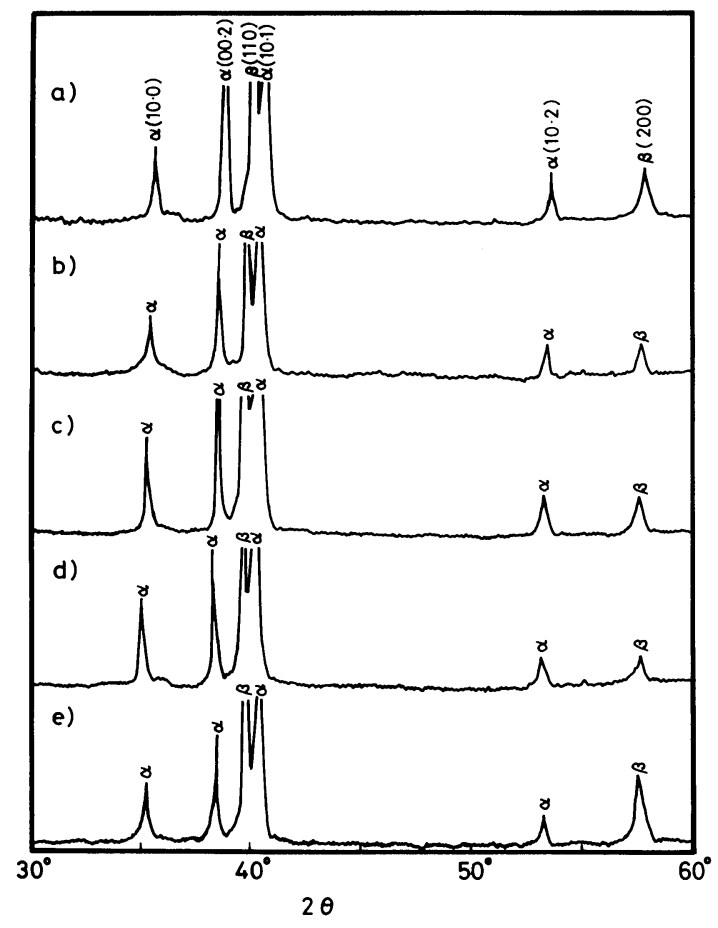

Fig.4 X-ray diffraction profiles of Ti-10V-2Fe$3 \mathrm{Al}$ alloy which was solution treated for $3.6 \mathrm{ks}$ at: (a) $973 \mathrm{~K}$, (b) $1023 \mathrm{~K}$, (c) $1043 \mathrm{~K}$, (d) $1073 \mathrm{~K}$, and (e) $1173 \mathrm{~K}$, and were aged at $783 \mathrm{~K}$ for 28.8 ks.

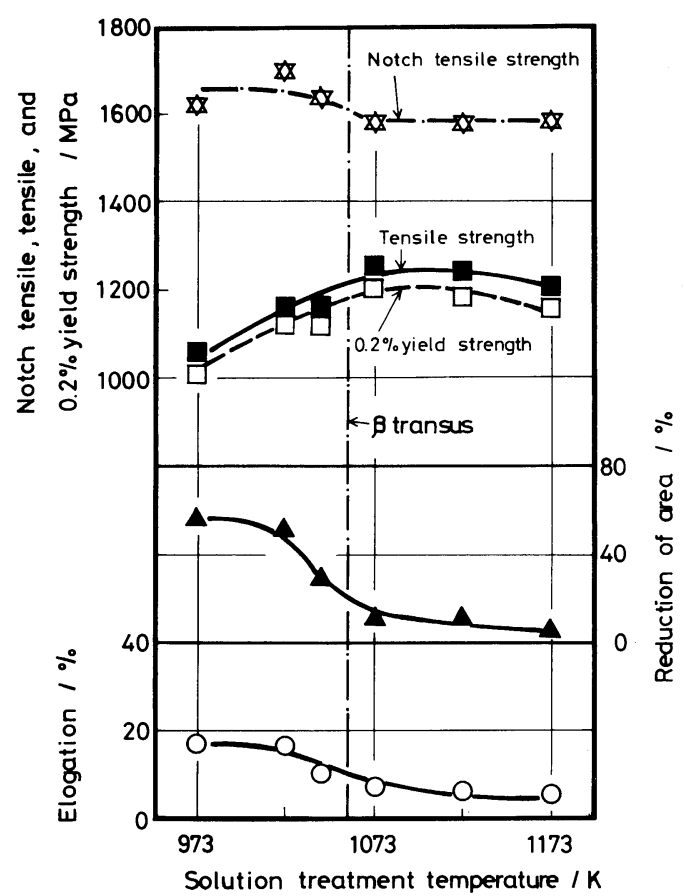

Fig.5 Effect of the solution treatment temperature on the tensile and notch tensile properties of $\mathrm{Ti}-10 \mathrm{~V}-2 \mathrm{Fe}-3 \mathrm{Al}$ alloy after aging at $783 \mathrm{~K}$ for $28.8 \mathrm{ks}$.
溶体化処理温度による変化も少ない。

Fig. 6 は， $K_{\text {IC }}$ におよぼす溶体化処理温度の影響を示し たむのである.973 Kのみ invalidの值を示し, $1023 \mathrm{~K}$

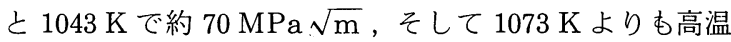
側では約 $60 \mathrm{MPa} \sqrt{\mathrm{m}}$ であった。 てのように $K_{\mathrm{IC}}$ は $\beta$ 変 態点以下では溶体化処理温度の上昇にともなって低下し， $\beta$ 単相域ではほぼ一定となる.

結局, $\beta$ 変態点直下の温度の溶体化処理で強度, 伸び, 切欠引張強さと $K_{\mathrm{IC}}$ の優れた組合せが得られた。 また, 絞りは溶体化処理温度に極めて敏感で, $\beta$ 变態点直下の温 度のなかでも $1043 \mathrm{~K}$ よりも $1023 \mathrm{~K}$ で高い值が得られた。

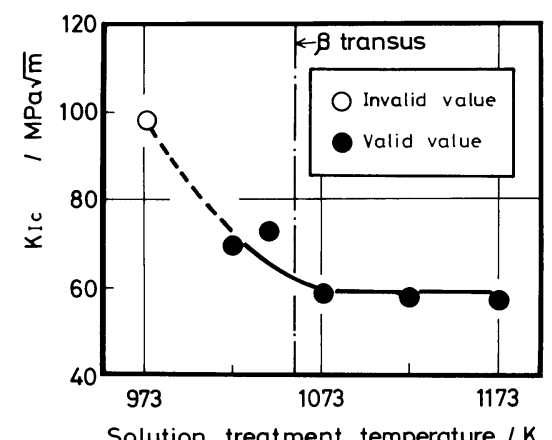

Fig.6 Effect of the solution treatment temperature on the fracture toughness of $\mathrm{Ti}-10 \mathrm{~V}-2 \mathrm{Fe}-$ $3 \mathrm{Al}$ alloy after aging at $783 \mathrm{~K}$ for $28.8 \mathrm{ks}$.

\section{IV. 考察}

\section{1. 応力誘起マルテンサイト変態の生成と消滅}

Fig.3の溶体化材の引張試験結果に扔いて, $1023 \mathrm{~K}$ か ら $1043 \mathrm{~K}$ にかけて $0.2 \%$ 耐力の急激な低下と伸びの著し い上昇を示した。乙れは，Fig.2の相同定結果からあ明ら かなように, $1043 \mathrm{~K}$ 以上の溶体化材の $\beta$ 相がやや不安定 なため, 引張試験中に応力誘起マルテンサイト変態が発

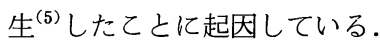

これらの溶体化材を $783 \mathrm{~K}$ で $28.8 \mathrm{ks}$ 時効処理すると， $0.2 \%$ 耐力は引張強さと同様の傾向を示し，また伸びも絞 りと同様の傾向となり, マルテンサイト変態の発生を示唆 する徴候が見られなくなる．乙のことから，溶体化時効材 では応力誘起マルテンサイト変態は発生していないと思わ れる.

Fig.7は，X 線回折の結果をもとに溶体化処理のままの 状態と, 時効処理後における $\alpha$ 相の総量と, $\beta$ 相の格子 定数の変化を示したものである. $\beta$ 相の格子定数は, $\alpha$ 相 0\%の $1073 \mathrm{~K}$ 以上の高温溶体化材ではほぼ一定の約 0.325 $\mathrm{nm}$ である. 溶体化処理温度が低下し, 初析 $\alpha$ 相が析出す るようになると $\beta$ 相の格子定数は減少する.ささらに, 時 効によって多量の $\alpha$ 相が析出すると， $\beta$ 相の格子定数が 著しく減少する. $\mathrm{Mo}, \mathrm{V}, \mathrm{Cr}, \mathrm{Fe}, \mathrm{Mn}$ などの原子半径の 小さい $\beta$ 安定化元素量が増加すると, $\beta-\mathrm{Ti}$ の格子定数は 


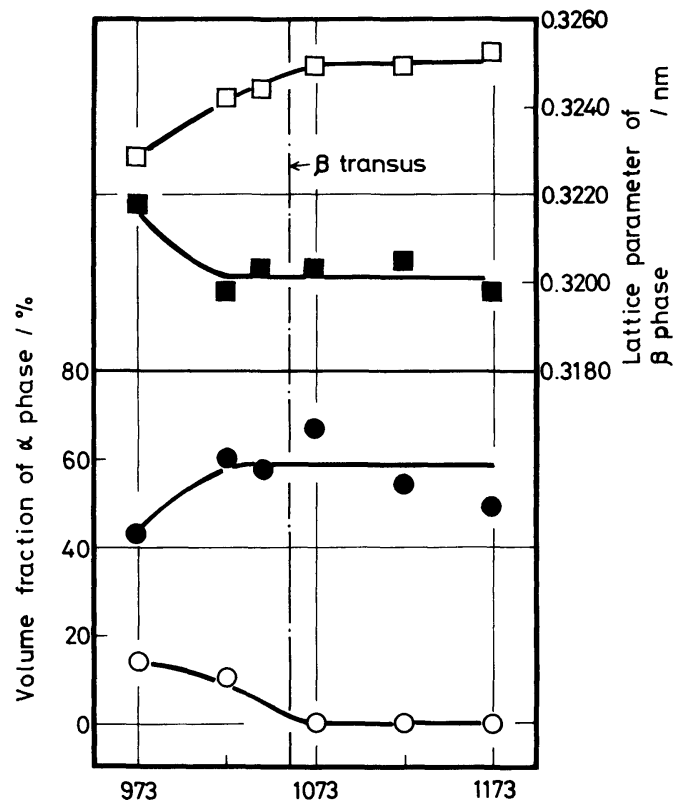

Solution treatment temperature $/ \mathrm{K}$

Fig.7 Effect of the solution treatment temperature on the lattice parameter of $\beta$ phase which was calculated from $2 \theta$ of (200) $\beta$ and the volume fraction of alpha phase in $\mathrm{Ti}-10 \mathrm{~V}-2 \mathrm{Fe}-3 \mathrm{Al}$ alloy. Open mark : as solution treated condition.

Solid mark : after aging at $783 \mathrm{~K}$ for $28.8 \mathrm{ks}$.

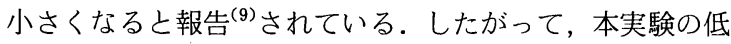
温溶体化材で格子定数が減少したのは, 溶体化処理温度が $\beta$ 変態点よりも低いため, 初析 $\alpha$ 相の析出により $\beta$ 相に $\beta$ 安定化元素の濃縮が生じ, $\beta$ 単相域溶体化の場合に比べ て $\beta$ 相の溶質元素濃度が高くなったためである. てのよ うな格子定数の減少に伴う $\beta$ 相の安定性の増加が, 低温 溶体化材に打ける応力誘起マルテンサイト变態が生じなく なる理由である.それに対して，783 K, $28.8 \mathrm{ks}$ 時効材で は, Fig.7 から明らかなように時効による $a$ 相の析出によ り $\beta$ 相の安定性が著しく高めら㭁ので, 応力誘起マル テンサイト変態がすべての溶体化処理温度で生じなくなっ たと考えられる。な扔， $973 \mathrm{~K}$ 溶体化時効材で $\beta$ 相の格 子定数が若干高くなったのは, かなりの量の初析 $\alpha$ 相が 析出して抢り $\beta$ 相の安定性を高め, 時効の際, 平衡状態 図に基づく量比の $\alpha$ 相の析出が抑制され，時効後の $\beta$ 相 の溶質元素の濃化が十分に進行していないためと思われる.

\section{2. 強度，延性，勒性におよぼす溶体化処理温度の影 響}

溶体化材の引張強さは, Fig.3に示したように, $1043 \mathrm{~K}$ 溶体化材から高温側ではほぼ一定の約 $800 \mathrm{MPa}$ を示し， 低温側の $1023 \mathrm{~K}$ と $973 \mathrm{~K}$ では約 $100 \mathrm{MPa}$ 高くなってい る. てれは，低温で溶体化処理すると，Fig.7亿示すよう に初析 $\alpha$ 相が析出するとともに, 溶体化前の加工の影響
が残っているためと考えられる．乙の両者の影響を分離す るととはできないが， $783 \mathrm{~K}$ で $28.8 \mathrm{ks}$ 時効すると，溶体 化状態でやや高い強度を示した低温溶体化材が高温溶体化 材よりあ 100〜 200 MPa 低い值を示し，Fig.5 亿示すよう に強度が逆転する。乙れは，Fig.7亿示すように $973 \mathrm{~K} の$ 低温溶体化材では, 溶体化処理状態ですでに初析 $\alpha$ 相が $10 \%$ あ析出し, 母相の $\beta$ 相の溶質濃度が高まり, 時効処 理に扮ける $\alpha$ 相の析出が抑制されたてとによるすのと考 えられる。

次に, 溶体化時効材の伸び, 絞り, 切欠引張強さ, $K_{\mathrm{IC}}$ の溶体化処理温度による変化が, 強度変化仁起因するのか, あるいは同一強度水準での組織变化仁起因したあのである のかを把握するため, 引張強さとの関係として示したのが Fig.8である.乙の図において，伸びと絞りは同じ傾向を 示すのでその変化が大きい絞りに注目すると, $1023 \mathrm{~K}$ か ら $1043 \mathrm{~K}$ にかけて強度がまったく変化していないにあか かわらず，絞りが 55\% から 30\% まで低下し，さらに 1073 K の約 10\% へ之低下している。乙のように，1023 K から $1073 \mathrm{~K}$ にかけては強度はほとんよ゙变わらないが，絞りは 約 $55 \%$ から $10 \%$ まで急激仁低下し，組織変化仁起因する 影響が明瞭仪認められる. Fig.9は, $1023 \mathrm{~K}$ と $1073 \mathrm{~K}$ の 溶体化時効材の引張破面である. $1023 \mathrm{~K}$ ではディンプル 破面を呈しているが，1073 Kになると粒界割れの混在し た破面に変化している。このように，延性に打よぼす溶体

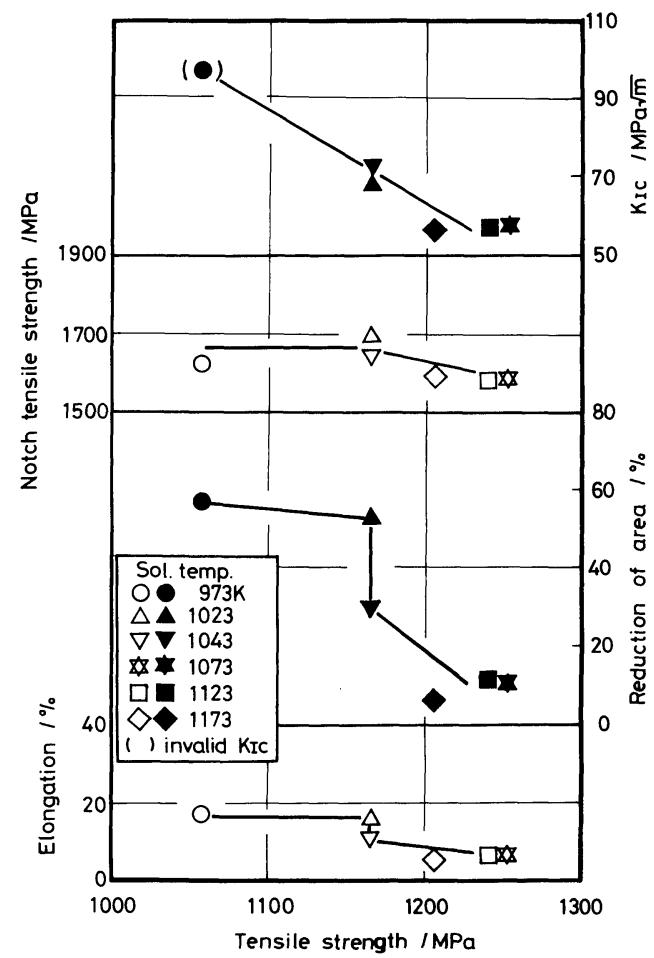

Fig.8 Relationship between tensile strength and elongation, reduction of area, notch tensile strength, and $K_{\mathrm{lc}}$ of $\mathrm{Ti}-10 \mathrm{~V}-2 \mathrm{Fe}-3 \mathrm{Al}$ alloy after aging at $783 \mathrm{~K}$ for $28.8 \mathrm{ks}$. 

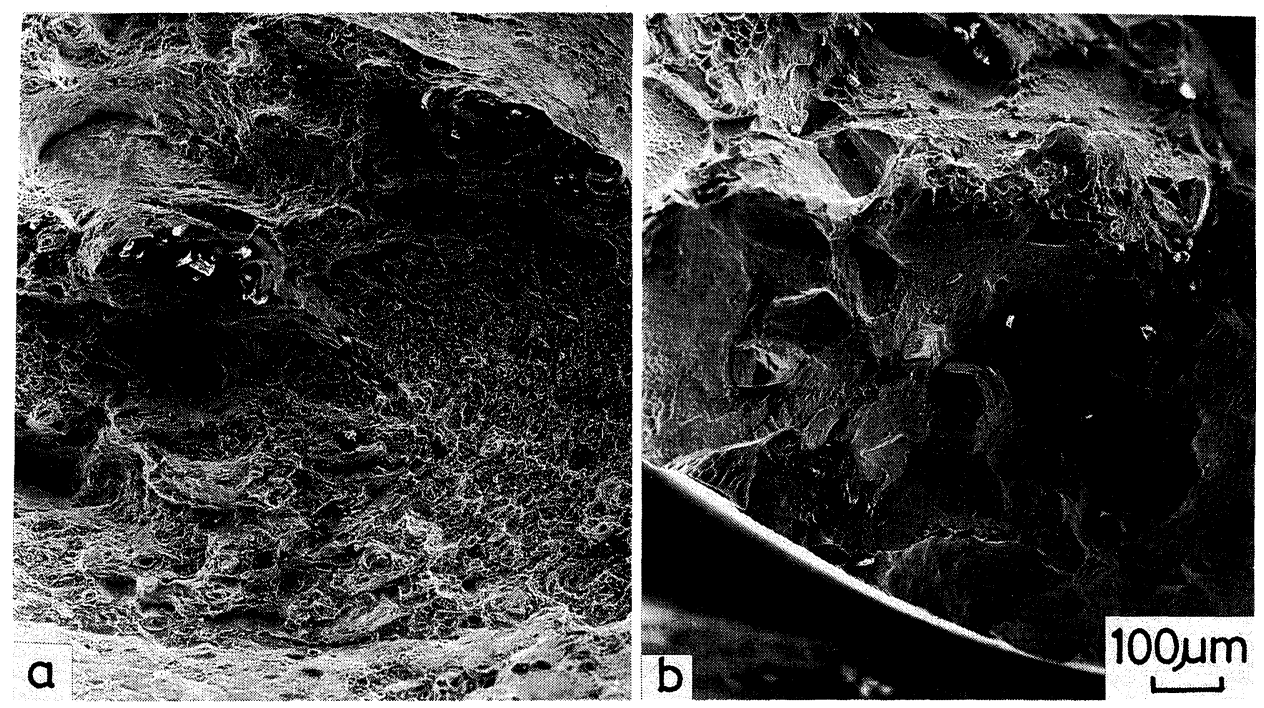

Fig.9 Scanning electron fractographs of the tensile specimens after aging at $783 \mathrm{~K}$ for $28.8 \mathrm{ks}$ in solution treated materials at: (a) $1023 \mathrm{~K}$ and (b) $1073 \mathrm{~K}$.

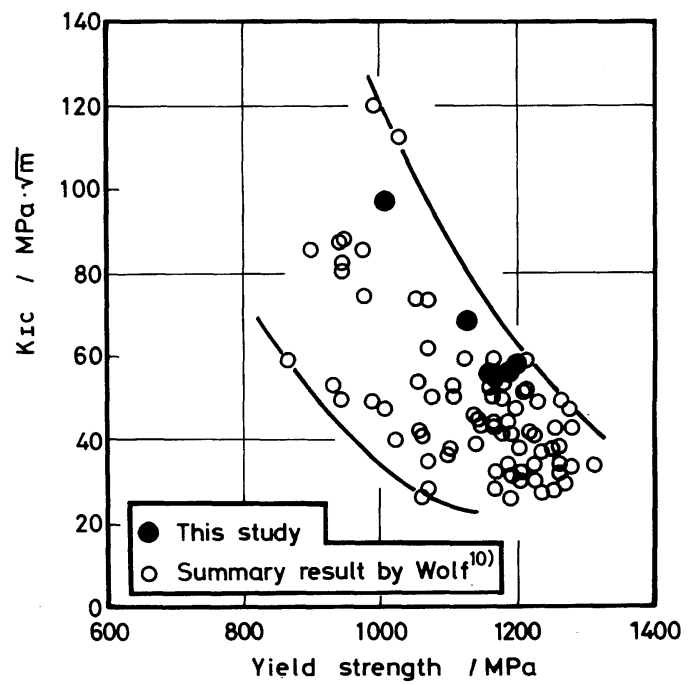

Fig.10 Relationship between yield strength and $K_{\mathrm{lc}}$.

化処理温度の影響としては粒界破壊を促進する組織变化が あげられる.しかしながら， $\beta$ 単相で結晶粒径が粗大化す る領域では，すでに延性值が低く，明瞭な粒径依存性を認 めることはできなかった。

切欠引張強さと $K_{\mathrm{IC}}$ は, 延性の場合とは異なる挙動を 示す．すなわち，切欠引張強さは，強度が上昇してあほぼ 一定であるのに対し， $K_{\mathrm{IC}}$ は強度の上昇にともない低下 する. しかし, 同一強度水準では延性にみられるような組 織変化の影響は現れていない。 また, 本実験の $K_{\mathrm{IC}}$ と $0.2 \%$ 耐力の関係は, Wolf $ら^{(10)}$ の収録した值と比較する と, Fig.10に示すように強度の上昇にとむない $K_{\mathrm{IC}}$ が低 下する傾向のほぼ上限にプロットされる。

このように，鞁性を表す両者が異なる挙動を示すことか
ら，材料を総合的に評価するには切欠引張強さと $K_{\mathrm{IC}}$ の いずれか一方だけで靱性を判断することなく，両特性を求 めることが必要であろう.

\section{V. 結 論}

$(\alpha+\beta) 2$ 相域から $\beta$ 単相域の種々の温度で溶体化処理 を施した Ti-10V-2Fe-3Al 合金について，組織と機械的 性質の関係を検討した。 その結果, 次のことが明らかとなっ た。

(1) $973 \mathrm{~K}$ から $1173 \mathrm{~K}$ までの温度で溶体化処理すると， $\beta$ 変態点よりも低温の $973 \mathrm{~K}$ と $1023 \mathrm{~K}$ では $(\beta+\alpha)$ の 2 相, $\beta$ 変態点直下の $1043 \mathrm{~K}$ で $\left(\beta+\alpha+\alpha^{\prime \prime}\right)$ の 3 相, そして $\beta$ 変 態点よりも高温の $1073 \mathrm{~K}$ から $1173 \mathrm{~K}$ の溶体化処理では $\left(\beta+\alpha^{\prime \prime}\right)$ の 2 相組織であった。 $\beta$ 相の結晶粒径は, $1073 \mathrm{~K}$ 溶体化処理で約 $150 \mu \mathrm{m}, 1173 \mathrm{~K}$ で約 $450 \mu \mathrm{m}$ であった.

(2) 溶体化材の引張強さは, $973 \mathrm{~K}$ の約 $800 \mathrm{MPa}$ から $1043 \mathrm{~K}$ の約 $700 \mathrm{MPa}$ へと低下するが, さらに溶体化処理 温度が上昇しても変化しない，とてろが，0.2\%耐力は， $973 \mathrm{~K}$ から $1023 \mathrm{~K}$ にかけてはゆるやかに低下するが 1043 Kになると急激に低下し，約 $450 \mathrm{MPa}$ となる．そして， 乙の耐力の低下と対照的に，伸びが大きく増加する.

(3) 乙の $0.2 \%$ 耐力と伸びの急激な变化は, $\beta$ 相の安定 性の低下に基づく応力誘起マルテンサイト変態の発生によ るものである。

(4) 溶体化時効材の引張強さは, $973 \mathrm{~K}$ から $1073 \mathrm{~K}$ に かけてはやや低下している． $0.2 \%$ 耐力は, 引張強さ之同 様の傾向を示し, 溶体化材のような特異な変化は示さない. そして, 延性は伸び, 絞りともに $973 \mathrm{~K}$ から $1023 \mathrm{~K}$ で高 く, $1073 \mathrm{~K}$ にかけて急激に低下し，1073 K 以上の高温で はゆるやかに低下する。乙の $1023 \mathrm{~K}$ から $1073 \mathrm{~K}$ にかけ 
ての延性の急激な低下は, 粒界破壊を促進する組織変化に 起因するが, $1073 \mathrm{~K}$ 以上の高温では延性の絶対値が低く, $\beta$ 粒径粗大化の悪影響は認められない.

(5) 一方, 切欠引張強さと $K_{\mathrm{IC}}$ は, 同一強度水準下で は組織の影響を受けない, そして, 切欠引張強さは, 強度 変化の影響む受けないのに対して， $K_{\mathrm{IC}}$ は強度水準のみ に依存する変化を示す。

(6) 最後に, 強度, 伸び, 絞り, 切欠引張強さおよび $K_{\mathrm{IC}}$ の優れた組合せは, $\beta$ 変態点直下の温度の溶体化処理 で得られることが明らかとなった。

\section{文献}

(1) ASM Metals Handbook, 9th ed., (1981), vol.4, p.330.

（2）外山和男, 前田尚志 : 鉄之鋼, 72(1986), 617 .
( 3 ) T.W.Duerig, G.T.Terlinde and J.C.Williams: Metall. Trans., 11A(1980), 1987.

(4) T. W. Duerig, J. Albrecht, D. Richter and P. Fischer: Acta Metall., 30(1982), 2161.

( 5 ) G.T.Terlinde, T.W.Duerig and J.C.Williams: Metall. Trans., 14A(1983), 2101.

(6) W. A. Reinsch and H.W. Rosenberg : Metal Prog., 117(1980), 64.

(7) ASTM Annual Book of ASTM Standards, Vol.03-01(1983), 518.

( 8 ) T.W.Duerig, R.M.Middleton, G.T.Terlinde and J.C.Williams: Titanium '80 Science and Technology, Ed, by H.Kimura and O.Izumi, AIME, (1980), 1503.

(9) W.B.Pearson: A Handbook of Lattice Specings and Structures of Metals and Alloys, Pergamon Press, London, (1958), 876.

(10) Aerospace Structural Metals Handbook No.4, Ed. by Mechanical Properties Data Center, Traverse, (1984). 